Spìvak et al. 1

Running title: Population structure and reproduction of Xantho poressa

\title{
Population structure and reproductive biology of the stone crab Xantho poressa (Crustacea: Decapoda: Xanthidae) in the "Corrales de Rota" (SW Spain), a human-modified intertidal fishing area.
}

Eduardo D. Spivak ${ }^{1}$, Elisabeth Arévalo $^{2}$, José A. Cuesta ${ }^{3}$ and J. Ignacio GonzálezGordillo $^{2}$

1) Departamento de Biología, Facultad de Ciencias Exactas y Naturales, Universidad Nacional de Mar Del Plata and Consejo Nacional de Investigaciones Científicas y Técnicas de la República Argentina. Casilla de Correo 1245, 7600 Mar del Plata, Argentina. E-MAIL: espivak@ mdp.edu.ar

2) Centro Andaluz de Ciencia y Tecnología Marinas, Campus Universitario de Puerto Real, Universidad de Cádiz, E-11510 Puerto Real, Cádiz, Spain. E-MAIL: nacho.gonzalez@uca.es

3) Instituto de Ciencias Marinas de Andalucía (CSIC), Avenida República Saharaui, 2, E-11510 Puerto Real, Cádiz, Spain. E-MAIL: jose.cuesta@icman.csic.es

\section{Abstract}

The present study describes the reproductive biology, population structure and life history traits of the abundant intertidal crab Xantho poressa. Between March 2007 and April 2008, a total of 1918 individuals were collected in Corrales de Rota (SW Spain), a human-modified intertidal habitat characterized by an artificial high complexity. Suitable refuges for crabs (cobbles and boulders) are very abundant in this area and density (maximum of 50 ind ${ }^{*} m^{-2}$ ) was directly related with the area covered by these stones. In spring and summer, size frequency distributions showed a polymodal pattern with seasonal variations related to the incorporation of juveniles to the adult population. Newly settled juveniles were not found in the corrales suggesting an 
Spìvak et al. 2

ontogenetic migration from a distant recruitment habitat. The annual reproductive cycle was seasonal and successive peaks in the abundance of ovigerous females were observed in late spring and summer. Females probably produced multiple broods during a long intermoult period. The gonadosomatic index had a cyclic pattern of variation with peaks two weeks prior to those of ovigerous females being low during the non-reproductive season. The hepatosomatic index was high during spring, decreased during summer and increased gradually at the end of the reproductive season. There was a monthly cycle of larval release resulting from a combination of a cyclic and synchronic ovarian maturity, oviposition and incubation; hatching took place during neap tides when moon was at last quarter. The adaptive significance of the rhythmic reproduction and hatching observed may not be explained by the predator avoidance hypotheses. The overall sex ratio did not differ from 1:1 but one male and several females coexist under a stone, indicating a female biased operative sex ratio. The combination of a complex habitat, its use, and a strong sexual dimorphism suggest a refuge-defense polyginic mating system. The survival and fitness of $\mathrm{X}$. poressa in the Corrales de Rota are probably enhanced by the availability of shelter, a consequence of a highly complex habitat, and probably, of human activity.

Keywords: Xanthidae, corrales de pesca, hepatosomatic index, gonadosomatic index, fecundity, handedness, rhythms, mating systems 
Spìvak et al. 3

\section{INTRODUCTION}

It is expected that biodiversity will play a role in sustaining ecosystem functions, goods and services (Duarte, 2000). The loss of structurally complex habitats due to human activity leads to significant changes in species identity, richness and abundance in temperate marine environments (Airoldi et al., 2008). The intertidal zone is among the coastal habitats which are more affected by anthropogenic impacts, both because of its usually easy access and because of the continuous pressure exerted by human development (Kaiser et al., 2005). In an attempt to preserve the high ecological level and socio-economical value of intertidal areas, some of these have been exceptionally assigned a protection status. Clear examples of such areas are the Corrales de pesca, human-modified fishing areas in Spain. The corrales are one of the most ancient methods of selective fishery, used for collecting shellfish and fish since Roman times, and an example of a sustainable exploitation of fishery resources (see Arias García, 2005). The protection status of Monumento Natural (Natural Monument) given by the regional government (prohibiting shellfish captures and over-exploitation of fish resources in the corrales) may preserve rocky intertidal habitats that provide shelter and food to a wide number of species.

A dense population of the crab Xantho poressa (Olivi, 1792) inhabits the Corrales de Rota, a corral de pesca located in Rota (Cádiz Bay), southwestern Spain. This species has been recorded throughout the entire Mediterranean and Black Seas, as well as in the northeastern Atlantic Ocean, from the Canary Islands to Portugal. It occurs at depths from 0 to $15 \mathrm{~m}$ and it is commonly found in the intertidal (particularly in the Atlantic) and the shallow subtidal zones, mostly under stones (González-Gordillo et al, 1990; D`Udekem D’Acoz, 1999; Reuschel \& Schubart, 2007). 
Spìvak et al. 4

The genus Xantho Leach, 1814 belongs to the family Xanthidae MacLean, 1838 sensu stricto, "one of the largest families in the Brachyura, despite several modern revisions and reassessments” (Ng et al., 2008). Four species of Xantho are currently recognized: X. hydrophilus (Herbst, 1790), X. pilipes A. Milne Edwards, 1867, X. poressa (Olivi, 1792), and X. sexdentatus (Miers, 1881). Ng et al. (2008) included a fifth species, $X$. granulicarpus Forest, 1953 but the validity of this taxon has been questioned (Reuschel \& Schubart, 2006 and references therein). Xantho sexdentatus is only found in the tropical and subtropical Atlantic, from Sahara to Senegal (D`Udekem D’Acoz, 1999); the other three species are distributed in the northeastern Atlantic as well as in the Mediterranean Sea (Reuschel \& Schubart, 2006). X. hydrophylus inhabits from western Scotland to the Gulf of Guinea, and X. pilipes from southern Scandinavia to Angola. Although the northeastern Atlantic populations of $X$. poressa are restricted to waters between the Canary Islands and Portugal, this species has the widest Mediterranean distribution, and it is the only one with records in the Black Sea (D`Udekem D’Acoz, 1999; Reuschel \& Schubart, 2006)

Despite the usual high abundance of $X$. poressa and the easy access to its habitat, there is scarce knowledge on the natural history of this species. Besides, the general studies of the European crustacean fauna (Zariquiey Alvarez, 1968; D`Udekem D’Acoz, 1999), Rodriguez \& Martin (1997) described the development of larvae reared in laboratory; Bedini (2002) studied color changes and mimicry from juvenile to adult; Reuschel \& Schubart $(2006,2007)$ compared the morphometry and genetics among Mediterranean and Atlantic populations, contrasted the genetic diversity with the phenotypic diversity in coloration and size, and added new information on its ecology. The only information available on the populational and reproductive biology of other Xantho species is limited to an estuarine population of $X$. pilipes and a marine 
Spìvak et al. 5

population of $X$. hydrophilus (as X. incisus), both in Portuguese waters (Paula, 1989; Flores and Paula, 2002b, respectively).

Therefore, the main goal of this paper is to study the habitat use, size distribution and sex ratio, the fecundity and reproductive cycle of $X$. poressa in this Atlantic population that lives in a particular, human-modified habitat, characterized by artificial changes in the availability of refuges and the abundance of predators.

\section{MATERIAL AND METHODS}

\section{Study area}

The study area is located near the northwestern limit of the Cádiz Bay, an inlet (11 x $8 \mathrm{~km}$ ) of the Gulf of Cádiz on the North Atlantic Ocean, southwestern Spain (Figure. $1 \mathrm{a}, \mathrm{b})$. The area is subjected to a semidiurnal tidal regime with a mean tidal range of $2 \mathrm{~m}$ which exerts great control on the ecosystem by providing water renewal rates of $30 \%$ during neap tides and 75\% during spring (Álvarez et al., 1999). The Corrales de pesca de $\operatorname{Rota}\left(36^{\circ} 37^{\prime} \mathrm{N}, 6^{\circ} 23^{\prime} \mathrm{W}\right)$ are enclosures in the intertidal zone, limited by stone walls (ca. $0.60 \mathrm{~m}$ height), with a surface area of $1.10 \mathrm{Km}^{2}$ (Figure 1c, e). The walls are perforated by several openings protected by grilles; walls and openings allow the sea to enter the area during high tides and trap the fish when the tide recedes. Apart from the walls, the whole area is a flat and almost horizontal platform partially covered by rocky fragments that were deployed in the bottom in order to increase the refuge availability for potential preys of fishes and cephalopods as crabs and other invertebrates. The size of the rocky fragments that cover the bottom of the corral was evaluated from photographs taken at 5 random sites in the sampling area; the surface of individual fragments was measured with the Skaletti 2.5 software, using a scale of $0.25 \mathrm{~cm}^{2}$ 
Spìvak et al. 6

squares (Figure 1d). These fragments were then classified by a modification of the American Geophysical Union Sediment Classification System (Lane, 1947) in the following categories: very coarse gravel $\left(<32 \mathrm{~cm}^{2}\right)$, small cobbles $\left(32-128 \mathrm{~cm}^{2}\right)$, large cobbles (129-512 $\left.\mathrm{cm}^{2}\right)$, small boulders (513-2048 $\left.\mathrm{cm}^{2}\right)$, medium boulders (2049-8192 $\left.\mathrm{cm}^{2}\right)$, large boulders $\left(8194-32768 \mathrm{~cm}^{2}\right)$ and very large boulders $\left(>32770 \mathrm{~cm}^{2}\right)$. The term "stone" (sensu lato) was used throughout the paper to designate all categories.

Monthly mean air and coastal water temperatures (2007-2008) ranged between $11.1^{\circ} \mathrm{C}$ (December) and $23.6^{\circ} \mathrm{C}(\mathrm{July})$ and between $15.8^{\circ} \mathrm{C}$ (March) and $22.8^{\circ} \mathrm{C}$ (September), respectively. From May to August, air temperature was the same as, or higher than water temperature; from September to April it was lower. Air temperatures were obtained from the "Estación meteorológica 84490 (LERT)" of the Metheorology National Agency of Spain; water temperatures were supplied by the Oceanic Data Base of the Spanish Port System, and corresponded to the buoy denoted "Cost_Cádiz (red costera)" (36 $\left.36^{\circ} \mathrm{N}, 6^{\circ} 20^{\prime} \mathrm{W}\right)$.

\section{Collection and sample analysis}

Crabs were collected by hand from under stones during low tides in two zones separated by ca $100 \mathrm{~m}$ : zone A in the center (seaward) and zone B near the wall of the second southeast corral (Figure 1c). A total of 20 samples were taken biweekly (from March to August 2007, $n=14$ ) or monthly (from September 2007 to April 2008, $n=6$ ). The highest sampling frequency coincided with the reproduction period of the target species (González-Gordillo et al., 2003). At the beginning of the study (March 20, April 4, and April 18, 2007) approximately 100 crabs were collected (exploratory samples). After May 2007, we searched for all crabs present in circular sampling units (SU area = $0.5 \mathrm{~m}^{2}, \mathrm{n}=10$ ) randomly placed in both zones (density samples). Each density sample was composed of five SUs. 
Spìvak et al. 7

Crabs collected in both sets of samples (exploratory and density) were sexed, and measured with a Vernier caliper (carapace width, $\mathrm{CW}$ ) to the nearest $0.1 \mathrm{~mm}$. Sex ratio and size frequency distribution of males and females (size-class interval: $2 \mathrm{~mm}$ ) were calculated for each zone. For each sampling date, morphologically mature females (i.e. the pleon reaches the coxa of pereiopods) $(n=10)$, and ovigerous females, if present ( $n$ $=10$ ), were frozen to death at $-20^{\circ} \mathrm{C}$. Their ovaries and hepatopancreas were carefully dissected, dried for $48 \mathrm{~h}$ at $80{ }^{\circ} \mathrm{C}$ and weighed individually to the nearest $0.1 \mu \mathrm{g}$; the exoskeleton and remaining organs were also dried for $48 \mathrm{~h}$ at $80^{\circ} \mathrm{C}$ and weighed individually to the nearest $0.01 \mathrm{~g}$. Eggs of ovigerous females were previously removed. The gonadosomatic and hepatosomatic index (GSI and HSI) were calculated as the ratio between the dry weight of the organ and the dry weight of the whole crab including the organ, and expressed as a percentage. Mean GSI and HSI were calculated for each sampling date.

All "density sample" units were photographed and each large boulder (>32770 $\mathrm{cm}^{2} ; \mathrm{n}=6$ to 10 ) was identified with a number. Surface measurements of the labeled stones were performed with the Skaletti 2.5 software, using a scale of $0.25 \mathrm{~cm}^{2}$ squares. Crabs present in each labeled stone were separately stored; remaining crabs in the SU were pooled together. The mean density of crabs in each zone (A and B) was calculated. Due to bad weather conditions, sampling could not be completed on August 19, 2007 and only 20 females were collected.

The reproductive season was defined by the presence of ovigerous females; their percentage with relation to the total number of females (sizes similar or higher than the smaller ovigerous ones) was calculated. Samples of 10 freshly laid eggs (3 replicates) removed from each of 10 ovigerous females were counted under a stereomicroscope, rinsed in distilled water, dried for $24 \mathrm{~h}$ at $60^{\circ} \mathrm{C}$ in pre-weighed tin cartridges, and re- 
Spìvak et al. 8

weighed in an ultra-microbalance to the nearest $0.1 \mu \mathrm{g}$. All females were frozen to death, sized, and their egg masses completely removed. Females and their_respective egg clutches were dried (for $48 \mathrm{~h}$ at $80^{\circ} \mathrm{C}$ ) and weighed separately; then, the average dry weight values (DW) of the 10 egg samples were used to estimate the total number of eggs in each female (fecundity). The reproductive effort (RE) was calculated as the egg mass dry weight $* 100$ / female dry weight without the eggs.

Ovigerous females collected at the beginning, middle and end of the reproductive season (May 16, July 16 and August 28, 2007, respectively) were placed individually in 11 flasks filled with continuously aerated seawater at ambient temperature (ca. $25^{\circ} \mathrm{C}$ ) and examined daily in order to detect larval release. During this period, animals were not fed, they were released after hatching.

Some ancillary samples were collected in order to study handedness and relative growth; changes in these characters during the year were not expected. Handedness was recorded in all crabs collected on April 18 and May 16, $2007(n=204)$. A collection of 140 males and females covering the whole size range of the species were obtained from different samples and used for evaluating sexual dimorphism of chelae. The propodus height of this limb and the carapace width were simultaneously measured in each individual.

\section{Statistical methods}

The temporal patterns of population density, size frequency distribution and sex ratio were studied seasonally and samples within a season were considered replicates. The temporal pattern of reproductive traits was studied comparing individual samples with no temporal replicates in order to detect changes before (HSI, GSI), after (HSI, GIS), and especially during (HSI, GIS, percentage of ovigerous females, female size, egg number, reproductive effort, and egg weight) the reproductive season. 
Spìvak et al. 9

The $\chi^{2}$ test was used to compare proportions, the $t$ test and Kolmogorov-Smirnov test to compare two means, and the ANOVA test to compare mean values of several treatments when variances were homogeneous (Brown-Forsythe Test). Data with heterogeneous variances were compared using Kruskal-Wallis tests.

Modes of size frequency distributions were fitted by the least squares method through the procedure proposed by Macdonald \& Pritcher (1979) and modified by Bas et al. (2005).

Quantitative relationships between carapace width and chelae height were described with least-square regressions (after $\mathrm{G}$ tests of homogeneity for normal distribution). Log-log regression slope values between 0.9 and 1.1 were considered indicative of isometry (“conservative definition”; Clayton, 1990: 285). Slopes of regression lines of males and females were compared with an analysis of covariance (ANCOVA). Differences were considered statistically significant when $\mathrm{P}<0.05$.

\section{RESULTS}

The Corrales de pesca de Rota are inhabited by several species of Brachyura, Anomura and Caridea that are, in part, spatially segregated. The following crabs were observed during the sampling period: Pachygrapsus marmoratus (highly abundant), $P$. transversus, Brachynotus atlanticus and Panopeus africanus in the high intertidal; Xantho poressa (highly abundant) and, ocassionally, X. hydrophylus, Pilumnus spinifer, Pisa armata, Macropodia spp., and small Carcinus maenas in the rest of the intertidal area; Eriphia verrucosa and also P. transversus in the stone walls. The anomuran fauna included the porcellanids Pisidia longicornis and Porcellana platycheles, and the hermit crabs Pagurus anachoretus and Clibanarius erithropus. Carideans found were 
Spìvak et al. 10

Palaemon elegans (highly abundant) and several alpheid species as Athanas nitescens and Alpheus dentipes.

During the entire study, 1918 specimens of X. poressa were collected: 1016 females, 869 males and 33 undifferentiated juveniles. Crab density varied between zones and between different sampling dates ranging from the absence of crabs in a SU (zone B on March 24, 2008) to 23 and $25 \mathrm{crabs} / 0.5 \mathrm{~m}^{2}$ in zones A and B, respectively (June 15, 2007). Density differed significantly between zones but not among seasons (two way ANOVA, Table 1): it was significantly higher in zone A with respect to zone B in summer and autumn $(12.7 \pm 4.88$ vs $10.2 \pm 3.65$ and $12.2 \pm 3.12$ vs $8.4 \pm 2.90$ crabs/0.5 $\mathrm{m}^{2}$ respectively, Newman-Keuls test, $\left.\mathrm{p}<0.5\right)$.

The sampling area consisted of a platform covered by sand and gravel (average: 53\%), and by stones (small and large cobbles, and small boulders; average: $47 \%$ ). Small cobbles were predominant in the area, followed by large cobbles, very coarse gravel and boulders; the proportion of stones occupied by at least one crab increased with stone size (Figure 2). The area of several stones found inside the sampling units was measured at different dates (May 16, June 15, July 2 and 31, August 28, 2007; n = 385) and ranged from 31 to $2200 \mathrm{~cm}^{2}$. The number of crabs per sampling unit was correlated with the proportion of the surface covered by stones $(y=0.43 x-2.45, r 2=0.548, n=54, p<$ 0.001). Crabs (ranging from 1 to 11) were found under 222 of these stones; those with crabs were significantly larger than stones without crabs $(t=6.36, \mathrm{df}=162, \mathrm{p}<0.0001)$. The number of crabs per stone was compared among small and large cobbles, and boulders; it increased significantly with stone area (Kruskal Wallis test, $\chi^{2}=13.91, \mathrm{df}=$ $2, p=0.0009)$

The largest male $(35.8 \mathrm{~mm} \mathrm{CW})$ and female $(28.8 \mathrm{~mm} \mathrm{CW})$ were found on October 28 and July 2, 2007, respectively. The smallest males and females with 
Spìvak et al. 11

noticeable external sexual dimorphism measured 6.1 and $6.2 \mathrm{~mm} \mathrm{CW}$, respectively. When data of samples corresponding to each season were pooled, the resulting sizefrequency distributions were apparently polymodal with 3-4 (males) or 2-3 (females) modal classes (= age groups); a pattern of size changes through the whole sampling period became evident (Figure 3, Table 2). The smallest size classes $(\mathrm{CW} \leq 11 \mathrm{~mm})$ were observed in spring (both sexes) and summer (females) suggesting the arrival of juveniles from recruitment areas; however a class of small males was present also in winter. The largest size classes appeared in spring and summer (males, $\mathrm{CW} \geq 30$; females, $\mathrm{CW} \geq 22.6$ ) but they were not observed in fall or winter, suggesting that large (and old) crabs disappeared from this habitat after summer. In addition, a displacement of modal classes could be observed: in males, from summer to fall, from fall to winter and from winter to spring; in females, from summer to fall and from winter to spring.

The overall sex-ratio did not deviate from the hypothetical $1: 1\left(\chi^{2}=16.46, \mathrm{df}=\right.$ $18, p=0.560)$ in most individual samples except on July $31,2007\left(\chi^{2}=4.130\right.$, $\mathrm{p}<0.050$ ). In addition, sex-ratios did not differ significantly when data were seasonally pooled (Kruskal-Wallis test: $\left.\mathrm{H}_{(3,19)}=2.976, \mathrm{df}=6, \mathrm{p}=0.395\right)$ and did not deviate from 1:1. The 1:1 sex ratio also predominated in cobbles and boulders hiding 2 crabs, but more females were usually present when 3 or more crabs were found (Figure 4). The proportion of males and females did not differ significantly when cobbles and boulders with only one crab were considered $\left(\chi^{2}=2.083, \mathrm{p}<0.149\right)$.

Ovigerous females were present from May 4 to August 19 appearing when air temperature equaled water temperature $\left(\mathrm{ca} .17^{\circ} \mathrm{C}\right)$; since May both temperatures increased, reaching $22-24^{\circ} \mathrm{C}$ at the end of the reproductive season (Fig. 5). The proportion of ovigerous females showed a biweekly oscillation (Figure 5); it was significantly higher in samples taken at new moon than in those taken at full moon 
Spìvak et al. 12

(mean values: $77.72 \pm 20.16$ and $22.55 \pm 9.30$, respectively; Kolmogorov-Smirnov Test, $\mathrm{p}<0.05$ ). Ovigerous females ranged from 12.6 to $23.9 \mathrm{~mm} \mathrm{CW}$. Larger females (24$28.8 \mathrm{~mm} \mathrm{CW}$ ) were never found in the ovigerous condition. During the reproductive season, female mean size was $17.0 \pm 2.12 \mathrm{~mm} \mathrm{CW}$ and did not differ significantly among samples and between reproductive conditions (ovigerous and non ovigerous; two way ANOVA, Table 3). The smallest male with a visible gonad measured $11.6 \mathrm{~mm}$ $\mathrm{CW}$ and the largest male without it measured $15.1 \mathrm{~mm} \mathrm{CW}$. Xantho poressa chelae were sexually dimorphic; the differences between sexes in the slopes of the log transformed relationship between carapace width and chelae height were significant (ANCOVA, Table 4). The relative growth of chelae was isometric in females $(y=$ $\left.0.25^{*} \mathrm{x}^{1.06}, \mathrm{R}^{2}=0.97\right)$ and positive allometric in males $\left(\mathrm{y}=0.11 * \mathrm{x}^{1.40}, \mathrm{R}^{2}=0.95\right)$.

The mean hepatosomatic and gonadosomatic indexes varied significantly through the year (ANOVA, HSI: $F_{(18,231)}=12.08$, GSI: $F_{(18,231)}=12.53$, $p<0.001$; Figure 6a, $\left.b\right)$. The mean HSI reached both its minimum (0.5-0.9) and maximum (7.5-11.5) in summer and did not differ between ovigerous and non-ovigerous females during the entire reproductive season $\left(\right.$ ANOVA, $\left.\mathrm{F}_{(2,94)}=0.89 \mathrm{p}=0.415\right)$. The mean GSI of nonovigerous females reached its maximum and minimum values in spring-summer (8.511.9) and in autumn-winter (0.03-0.19), respectively (Figure 6b). However, values differed significantly between non-ovigerous and ovigerous females (with early and late embryos) during the reproductive season $\left(\operatorname{ANOVA}_{(2,94)}=33.09, \mathrm{p}<0.0001\right)$ : the lowest and highest GSI corresponded, respectively, to females with early embryos and to non-ovigerous females (Figure 6c).

The number of eggs carried by a female ranged from 2400 to 14600 , and was correlated with female size $\left(y=2.50 * x^{2.67}, R^{2}=0.62\right)$. Mean fecundity was $5329.26 \pm$ 2392.39 eggs $(n=42)$, mean reproductive effort was $8.58 \pm 3.11 \%$ and mean dry weight 
Spìvak et al. 13

(DW) of a recently laid egg was $10.8 \pm 1.45 \mu \mathrm{g}$. Fecundity was significantly lower at the end of the reproductive season $\left(\mathrm{ANOVA}, \mathrm{F}_{(4,44)}=4.33, \mathrm{p}=0.005\right)$ but reproductive effort did not vary significantly among samples (ANOVA, $F_{(5,47)}=2.59, p=0.038$; Figure 7). Egg DW decreased significantly through the reproductive season (ANOVA, $F_{(3,112)}=10.74, p<0.0001$, Figure 7). Larval hatching of females brought to the laboratory in May, July and August, 2007 took place during the following neap tide (Figure 8) always at night; the tidal amplitude was significantly lower in "hatching days" than in "non-hatching days" $\left(\mathrm{t}_{(32)}=3.89, \mathrm{p}=0.0005\right)$.

Xantho poressa males and females were significantly right handed (81.5 and 81.1\% respectively, $\mathrm{n}=204$, two samples: April 18, May 4; test of difference between 2 proportions: $\mathrm{p}<0.0001)$. Handedness did not differ between sizes (crabs larger and smaller than $20 \mathrm{~mm} \mathrm{CW}$ ) nor between sexes (test of difference between 2 proportions: $\mathrm{p}$ $=0.745$ for size and $\mathrm{p}=0.859$ for sex).

\section{DISCUSSION}

\section{Abundance and habitat use}

The density of Xantho poressa in Rota was relatively constant throughout the year although it varied in space; it averaged $20 \mathrm{ind}^{*} \mathrm{~m}^{-2}$ (maximum: $50 \mathrm{ind}^{*} \mathrm{~m}^{-2}$ ), a high value when compared to similar temperate stony habitats. For example, in Tanabe Bay, Japan, densities of 4 intertidal crab species with similar sizes reached maximum values of 11 ind $* \mathrm{~m}^{-2}$ (Lohrer et al., 2000). However, densities of 100 ind $^{*} \mathrm{~m}^{-2}$ were observed in tropical intertidal xanthoids (Engstrom \& Lucenti, 1984). 
Spìvak et al. 14

The number of $X$. poressa individuals per square meter was directly related to the area covered by stone fragments as in $H$. sanguineus that invaded the norteastern coasts of USA (Ledesma \& J. O'Connor, 2001). Using the grade scale proposed by the American Geophysical Union (Lane 1947), X. poressa was found beneath small cobbles, large cobbles, and small boulders during low tides. Moreover, they employed many of the available cobbles (27 to 57\%, small and large, respectively) and most available boulders (92\%) (Figure 2). The habitat preferences of this species in the corrales agreed with that found in the shallow subtidal zone of the Mediterranean Sea: crabs preferred large boulders "with a rocky underground consisting of small pebbles" in areas with little rock displacement and were almost never found on sandy-dominated shores (Reuschel and Schubart, 2007).

The substrate determines the kind of refuge used by intertidal crabs: burrows in sandy and muddy beaches (e.g.: many Ocypodid and Grapsoid species), holes and crevices in large rocks with irregular surfaces (Abele et al., 1986), and boulders and cobbles in fragmented rocky shores (several species of stone crabs, Lohrer et al. 2000, $X$. poressa, this study). Moreover, there are two contrasting strategies of habitat use: to be active during low tides, remaining in refuges during high tide, and viceversa. Pachygrapsus socius, that lives on large rocks in the Pacific coasts of Panamá, and the coral rubble crab Cataleptodius floridanus, are examples of the first strategy (Abele et al., 1986; Engstrom \& Lucenti, 1984); Hemigrapsus sanguineus, several brachyuran and anomuran crab species found in cobble and boulder habitats of Japan (Lohrer et al., 2000 and references thereof) and X. poressa, are examples of the second. During this study, active crabs were never observed at low tide; they remained immobilized (the “freeze response" described by Knudsen, 1960) or buried in the substrate composed of sand and pebbles when the refuges were removed. Although the behaviour of X. poressa 
Spìvak et al. 15

during high tides has not been studied in the field up to this moment, they were active and mobile in aquarium (Cuesta, personal observation). Crabs stayed under stones in the subtidal zone during the day (Reuschel and Schubart, 2007) but the pattern of refuge use when they are continuously submerged (i.e.: in the Mediterranean) remains unknown.

Although experimental evidences (manipulation: shelter removal and addition as in Lohrer et al., 2000) are still lacking, the survival and fitness of $X$. poressa and other crab and crab-like species in the Corrales de Rota may probably be enhanced by the availability of shelter, a consequence of a highly complex habitat and indirectly, of human activity. This complexity has probably been achieved by generations of fishermen interested in increasing the availability of refuges for fishes and cephalopods. Shelter may decrease physiological stress, increase the ability for osmo and thermoregulation (McGaw 2001, 2003) and reduce the vulnerability to predators, even allowing crabs to forage without the risks of predation (Lohrer et al., 2000). In addition, complex habitats may provide more food than those structurally simple due to the accumulation of organic detritus in crevices and depressions and to the relatively great surface area that increases the space available for prey items (Lohrer et al., 2000). It would be interesting to test the relationship between refuge availability and $X$. poressa abundance through the comparison of the population in the corrales with the population in El Chato beach, a nearby rocky shore close to the city of Cádiz which apparently has both less refuges and crabs (Cuesta \& González Gordillo, unpublished).

The advantages of complex habitats may be counterbalanced by competitive interactions among co-occurring species affecting densities and distributions; the spatial segregation of crab species observed in Rota could reduce the interspecific competition but, again, experimental evidences are lacking. Corrales de Rota is very appropriate for experimental testing of both inter (e.g.: between X. poressa and Pachygrapsus 
Spìvak et al. 16

marmoratus or Panopeus africanus) and intraspecific (e.g.: between size classes;

Iribarne et al. 1994; Beck, 1997) competition among intertidal crabs.

\section{Growth}

Seasonal size-frequency distributions of $X$. poressa were polymodal and their changes among seasons suggested seasonal trends (Figure 3). The incorporation of juveniles to the adult population from putative nursery areas (see below) took place in spring and summer when small size classes were present; the class of small males observed in winter could be the result of the slower growth of late recruits. Female growth was minimum during breeding months, intense from late winter to early spring (as described for intertidal Pachygrapsus marmoratus from Portugal; Flores and Paula, 2002a, b), and from late summer to fall after the breeding season. Male growth appeared to be more continuous: a displacement of modal classes was observed between summer and fall, fall and winter and winter and spring (Figure 3). Although direct evidence is lacking, the absence of large crabs during fall suggests that old individuals, recruited during the previous year die after summer.

\section{Recruitment}

Most specimens of $X$. poressa found in the corrales were sexually differentiated. We found few (ca. 1.5\%) undifferentiated crabs, always larger than $3 \mathrm{~mm} \mathrm{CW}$; those between 3 and $5 \mathrm{~mm} \mathrm{CW}$ were very scarce. The absence of small crabs in the sampled area could be explained by a hypothetical spatial segregation, with recruitment taking place in a different habitat followed by migration episodes. A similar pattern was 
Spìvak et al. 17

suggested for the tropical ocypodid Dotilla fenestrata (Litulo et al., 2005). This type of ontogenic migrations have been well documented for the blue crab Callinectes sapidus: megalopae enter into estuaries but settle and metamorphose to the first benthic instar in nursery habitats, generally composed of aquatic vegetation such as seagrass meadows and salt marshes. Juveniles may remain in these areas until the seventh instar although early instars can return to the water column to undergo pelagic secondary dispersal (Reyns et al., 2006 and references therein).

Bedini (2002) suggested that juvenile $X$. poressa $(<8 \mathrm{~mm}$ carapace length, ca. 14 mm CW) live in Posidonia oceanica seagrass meadows of the Mediterranean Sea until the puberty moult (12-13 mm carapace length, ca.19-20 $\mathrm{mm} \mathrm{CW})$; then adults would leave the meadows and migrate to the nearest rocky substrate. However, Reuschel and Schubart (2007) rarely found X. poressa in P. oceanica and argued that Bedini's (2002) inference was based only on a small number of crabs collected during 2 years by SCUBA diving at a depth of 20-30 m. The scenario proposed by Bedini (2002) did not agree with data from the population that lives in the Corrales de Rota, which included males and females larger than $8 \mathrm{~mm} \mathrm{CW}$ and smaller undifferentiated individuals. The possible existence of a nursery habitat located on the bed of seagrasses found near the corrales (Arias García, 2005) should be investigated.

\section{Reproductive schedule}

Ovigerous females of $X$. poressa were present in late spring and summer, as it happens with other intertidal crabs of the region living in similar habitats (e.g.: Pachygrapsus marmoratus in central Portugal; Flores \& Paula, 2002a, b). The gonadosomatic index has a cyclic pattern of variation with peaks occurring two weeks 
Spìvak et al. 18

before those of ovigerous females (Figures 5 and 6); the first peak was the highest one and the last peak the lowest, suggesting that the degree of ovarian replenishment decreases during the reproductive season. During the non-reproductive season, the GSI was always low. The hepatosomatic index was high during spring, when females accumulate reserves, and decreased during summer, when nutrients stored in the hepatopancreas should be transferred to the ovaries. At the end of the reproductive season, the reserves gradually increased (Figure 6a). A similar general pattern was present in the intertidal pilumnidae Pilumnus vespertilio, a species that produce several broods during the reproductive season; however, the oscillations of GSI during this season were not observed, probably due to a lesser sampling frequency (Kyomo, 2002). A sharp decrease in early autumn may indicate that reserves could later be used for moult. Somatic growth and reproductive processes are considered antagonistic or competitive in crabs and other malacostracans (Nelson, 1991); females usually moult after the reproductive season. Although a synchronic female moult was not observed in $X$. poressa during this study, the increment of the modal size class of females between summer and autumn (Figure 3) suggest that a period of growth followed reproduction. In addition, since a new cohort of oocytes maturated while females were still ovigerous (Figure 6c), we hypothesize a schedule of moulting and reproduction in $X$. poressa females that would consist of multiple broods during a long intermoult period as it was described by Nelson (1991: 84, Figure $4 \mathrm{f}$ or $4 \mathrm{~g}$ ). However, it is necessary to investigate if this pattern is the result of one copula followed by several extrusions, as in Parathelphusa hydrodromous, or by one copula per brood, as in Neopanope sayi (Nelson, 1991 and references therein).

\section{Fecundity and reproductive effort}


Spìvak et al. 19

The mean investment per brood in dry weight terms calculated for X. poressa (8.6\%) was similar to the values mentioned for many free living crabs (Hartnoll, 2006, and references hereof). As many other crabs, $X$. poressa females produce more than one brood per year; considering the 4 peaks of ovigerous females as 4 broods, the annual investment of $X$. poressa in Rota could reach ca. $40 \%$, although the fecundity and egg dry weight diminished at the end of the season. The annual investment of temperate free living species ranges from 6-64\%, with a mean of 22\% (Hartnoll 2006).

Xantho poressa (this paper) and X. hydrophilus (as X. incisus, Flores \& Paula, 2002b) reached sexual maturity at similar sizes, though the maximum size of both sexes were higher in the latter. Coincidently, the mean fecundity was comparatively lower in $X$. poressa than in $X$. hydrophilus: 4500 vs 7600 eggs per female.

\section{Larval release rhythms}

Many intertidal crabs (e.g.: Ocypodidae, Grapsoidea, Xanthoidea; see Christy 2007 and references therein) have biweekly or monthly cycles of larval release mainly synchronized with tidal amplitude (Morgan 1996), though moonlight entrains spawning in at least one species (Saigusa 1988). Tidal amplitudes normally reach a maximum every new and full moon, but one of them usually has higher tides than the other. Moreover, tidal dominance by one lunar phase is not constant, it switches between new and full moon every seven months generating a 14-month "syzygy inequality cycle" (Skov et al. 2005).

Evidences obtained during this study suggest a monthly cycle of larval release in $X$. poressa. Hatching took place during neap tides when moon was at last quarter 
Spìvak et al. 20

(Figure 8). This rhythm seems to be a combination of a cyclic and synchronic ovarian maturity, oviposition and larval release (Figure 8), and also a similar incubation time (unknown in X. poressa). Our results agree with Kyomo (2002) in that periodicity in hatching of brachyurans is "just one and the last event of the egg-carrying period", and that copulation, spawning, and incubation periods are synchronized so that "each episode leads to the production of offsprings during appropriate hatching conditions"; however, these conditions (tidal amplitude) vary between $X$. poress $a$ (this paper) and Pilumnus vespertilio (Kyomo, 2002). In addition, the GSI peaks observed in this study (Figure 6b) and their increase during embryonic development (Figure 6c) suggest that, at least in $X$. poressa, oocyte maturity should also be synchronized with spawning.

A study of the temporal pattern of decapod larvae in a Portuguese estuary showed that a semilunar rhythm, centered on neap tides around quarter moons, characterized most species except X. pilipes and Carcinus maenas (Paula, 1989). The author suggested that larvae of these two crabs were retained in the estuary whereas those from the other species were exported to the sea; if it was true, a hatching rhythm could be masked. On the other hand, hatching is asynchronic in the low intertidal and subtidal $X$. hydrophilus (as X. incisus, Flores \& Paula, 2002b), indicating that there would be interspecific variability in the larval release activity of Xantho species.

The adaptive significance of larval release cycles was explained by the synchrony hypothesis (direct density-dependent benefits of simultaneous reproduction among individuals regardless of the timing of reproduction) and the timing hypothesis (individuals benefit by reproducing at a particular phase of a physical or biological cycle that is correlated with the lunar and tidal cycles) (Christy, 2003). As an example of the latter, the combination of larval release in the early evening and during the highest amplitude high tides would have a determinant adaptive value. Christy (2003) 
Spìvak et al. 21

examined the different hypotheses proposed to explain why most larvae leave estuaries and shallow coasts at night, when the tide recedes, and concluded that most evidences support the "predator avoidance hypothesis": the timing of larval release with large amplitude nocturnal ebb tides may be an adaptation to allow vulnerable, newly-hatched larvae to escape planktivorous fish that are especially abundant nearshore and less common in the coastal ocean (Christy, 2003 and references therein). However, this combination is not universal (Christy, 1986; Paula, 1989). For instance, Christy (1986) found that intertidal crabs on an exposed shore released their larvae over crepuscular neap high tides and suggested that it would not be necessary for these crabs to synchronize with spring high tides, as they would not need higher amplitude tidal currents to disperse their larvae.

In the context of the "predator avoidance hypothesis", to be vulnerable means having a contrasting color or small spines. For instance, larvae of fiddler crabs and other species that migrate from estuaries have small spines and are characterized by marked reproductive cycles. On the contrary, "larvae that are protected by spines or cryptic colors do not migrate from shallow waters, and adults of the species with these larvae lack the strong temporal patterns of reproduction that characterize species with vulnerable larvae" (Christy, 2007). Larvae of X. poressa are spiny (Rodríguez \& Martin, 1997) and after being released during neap tides they would remain in shallow waters avoiding predators. Hatching when moon is at the last quarter has not an obvious adaptive value. Consequently, the significance of the rhythmic reproduction and hatching observed in the Corrales de Rota should be explained by the synchrony or timing hypotheses other than "predator avoidance". For example, hatching when there is small tidal amplitude may imply a reduced probability of a newly laid larva to remain for a long time in an isolated tide pool. 
Spìvak et al. 22

\section{Handedness}

The cheliped of crabs is a "multifunctional organ" used for feeding, agonistic behaviours, reproduction and burrowing (Lee, 1995). Crabs with larger right claws predominate in both sexes of $X$. poressa, as it was observed in most carnivorous portunids and xanthids ( $>70 \%$ of dextral individuals in a population; Shigemiya, 2003 and references therein). It has been proposed that right-handedness is advantageous in breaking dextral shells by molluscivorous crabs, the predominant shell form in marine snail species ( $\mathrm{Ng} \&$ Tan, 1985), although some bivalve predators are also right handed (Milke \& Kennedy, 2001). Heterochely and handedness in crabs may arise through minor differences in an individual crab's use of its right and left claws or it may be the result of a genetic predisposition towards right handedness. In this latter case individuals with larger right chelae predominate in a population and left handedness is the result of major chelae loss and subsequent handedness reversal (Ladle \& Todd, 2006). Both sexes of the stone crabs Menippe mercenaria begin life right-handed but later the proportion declines to $80 \%$ and remains relatively constant (Simonson, 1985). The handedness of $X$. poressa recruits and early juveniles could not be studied but the proportion of right and left major chelae among the size classes present in the corrales did not differ from $80 \%$

\section{Sex ratio, sexual dimorphism and mating system}

The association of one male with several females of $X$. poressa under a cobble or a boulder frequently observed in the Corrales de Rota (Figure 4) suggests that this crab 
Spìvak et al. 23

would have a polygynous mating system. The overall sex ratio was 1:1 throughout the year but, since there were successive peaks in the abundance of ovigerous females (Fig. 5), the operative sex ratio varied during the reproductive season and data suggest a strong competition for females. In general, female crabs may be soft (postmoult) or hard (intermoult) at mating (Hartnoll, 1969); the moult stage of $X$. poressa females at mating is not known and should be investigated, but they are likely to copulate during the intermoult, as it occurs in X. hydrophilus (as X. incisus; Hartnoll, 1969).

The chelae of $X$. poressa are sexually dimorphic, larger in males than in females of the same size, as it also occurs in X. hydrophilus (as X. incisus, Flores \& Paula, 2002b). In addition, males reached larger sizes than females. Orensanz \& Gallucci (1988) stated that "pattern of dimorphism is consistent with inference on mating systems" and added that dimorphism in size of chelae is often associated with sexual selection. In Cancer species, large male chelae, especially if they appeared early in life history, was related with the defense of territories that would be held for a long time (Orensanz \& Gallucci, 1988) and with structured habitats (Orensanz et al., 1995). The combination of dimorphism and complex habitat also characterized $X$. poressa. However, reproductive synchrony was associated with less structured habitats in Cancer (Orensanz et al., 1995) and with much structured habitats in X. poressa.

According to Christy (1987), male crabs obtain mates in three general ways (female centered competition, resource centered competition and encounter rate competition) which are the result of a large set of variables including sex ratio, sexual dimorphism, habitat complexity (=availability of refuges), and reproductive synchrony (Orensanz \& Gallucci, 1988; Orensanz et al., 1995). Although it is necessary to evaluate the fidelity of crabs to a particular boulder, to observe their mating behaviour and to measure the operative sex-ratio, the hypothesis of a refuge defense mating system in $X$. 
Spìvak et al. 24

poressa seems plausible. The abundance of this population and its easy access will certainly allow testing it in future studies.

\section{AKNOWLEDGMENTS}

This study was partially carried on during a 6-month visit of EDS to the Instituto de Ciencias Marinas de Andalucía (ICMAN), supported by the Ministerio de Educación y Ciencia de España (MEC) through a grant for foreign professors and researchers visiting laboratories in Spain during their sabbatical years (SAB2005-0170). EDS would like to aknowledge the MEC for funding the travelling and living expenses, the ICMAN for the use of the installations, the Organismo Público Puertos del Estado (Spain) for providing excellent hydrographic information, and the Universidad Nacional de Mar del Plata (Argentina) for the sabbatical license; special thanks must go to the authorities and members of the ICMAN for the excellent time spent in Puerto Real. Ana Cosulich revised the English version.

\section{REFERENCES}

Abele L.G., Campanella P.J., Salmon M. (1986) Natural history and social organization of the semiterrestrial grapsid crab Pachygrapsus transversus (Gibbes). Journal of Experimental Marine Biology and Ecology 104, 153-170.

Airoldi L., Balata D., Beck M.W. (2008) The Gray Zone: Relationships between habitat loss and marine diversity and their applications in conservation. ). Journal of Experimental Marine Biology and Ecology 366, 8-15. 
Spìvak et al. 25

Álvarez O., Izquierdo A., Tejedor B., Mañanes R., Tejedor L., Kagan B.A. (1999) The influence of sediment load on tidal dynamics, a case study: Cádiz Bay. Estuarine, Coastal and Shelf Science 48, 439-450.

Arias García A.M. (2005) El monumento natural de Andalucía. Corrales de Rota. Sevilla, Ediciones de la Junta de Andalucía

Bas C., Luppi,T., Spivak E. (2005) Population structure of the South American estuarine crab, Chasmagnathus granulatus (Brachyura: Varunidae) near the southern limit of its geographical distribution: comparison with northern populations. Hydrobiologia 537, 217-228.

Beck M.W. (1997) A test of the generality of the effects of shelter bottleneck in four stone crab populations. Ecology 78, 2487-2503.

Bedini R. (2002) Colour change and mimicry from juvenile to adult: Xantho poressa (Olivi, 1792) (Brachyura, Xanthidae) and Carcinus maenas (Linnaeus, 1758) (Brachyura, Portunidae). Crustaceana 75, 703-710.

Christy J.H. (1986) Timing of larval release by intertidal crabs on an exposed shore. Bulletin of Marine Science 39, 176-191.

Christy J.H. (1987) Competitive mating, mate choice and mating associations of brachyuran crabs. Bulletin of Marine Science 41, 177-191.

Christy J.H. (2003) Reproductive timing and larval dispersal of intertidal crabs: the predator avoidance hypothesis. Revista Chilena de Historia Natural 76, 177-185.

Christy J.H. (2007). Predation and the reproductive behavior of fiddler crabs (genus Uca). In Thiel M. and Duffy J.E. (eds) Evolution of Social Behavior of Crustaceans. Oxford: Oxford University Press, pp. 211-231.

Clayton, D.A. (1990) Crustacean allometric growth: a case of caution. Crustaceana 58: 270-290. 
Spìvak et al. 26

Duarte, C. M. (2000) Marine biodiversity and ecosystem services: an elusive link. Journal of Experimental Marine Biology and Ecology 250, 117-131

d'Udekem d'Acoz C. (1999). Inventaire et distribution des crustacés décapodes de l'Atlantique nord-oriental, de la Méditerranée et des eaux continentales adjacentes au nord de $25^{\circ}$ N. Collection Patrimoines Naturels. Muséum national d'Histoire Naturelle: Paris, France, nº 40, 383 pp.

Engstrom N.A., Lucenti J.M. (1984) Time-lapse movies and the diurnal time budget and activity patterns of Cataleptodius floridanus, a tropical intertidal xanthid crab. Journal of Crustacean Biology 4, 266-276.

Flores A.A.V., Paula J. (2002a) Population dynamics of the shore crab Pachygrapsus marmoratus (Brachyura: Grapsidae) in the central Portuguese coast. Journal of the Marine Biological Association of the United Kingdom 82, 229-241.

Flores A.A.V., Paula J. (2002b) Sexual maturity, larval release and reproductive output of two brachyuran crabs from a rocky intertidal area in central Portugal. Invertebrate Reproduction and Development 42, 21-34.

González-Gordillo J.I., Cuesta J.A., Pablos F. (1990) Adiciones al conocimiento de los crustáceos decápodos de las zonas mediolitoral e infralitoral de las costas suratlánticas andaluzas (Suroeste España). I Brachyura. Cahiers de Biologie Marine 31, 417-429.

González-Gordillo J.I., Rodríguez A. (2003). Comparative seasonal and spatial distribution of decapod larvae assemblages in three coastal zones off the southwestern Iberian Peninsula. Acta Oecologica 24, 219-233.

Hartnoll R.G. (1969) Mating in the Brachyura. Crustaceana 16, 163-181.

Hartnoll R.G. (2006) Reproductive investment in Brachyura. Hydrobiologia 557, 31-40. 
Spìvak et al. 27

Iribarne O., Fernández M., Armstrong D. (1994) Does space competition regulate density of juvenile Dungeness Crab Cancer magister Dana in sheltered habitats. Journal of Experimental Marine Biology and Ecology 183, 259-271.

Kaiser M.J., Attrill M., Jennings, S., Thomas D.N., Barnes, D.K.A., Brierley A.S., Polunin N.V.C., Raffaelli D.G., Williams P.J.le B. (2005). Marine ecology: processes, systems, and impact, Oxford: Oxford University Press.

Knudsen J.W. (1960) Aspects of the Ecology of the California Pebble Crabs (Crustacea: Xanthidae). Ecological Monographs 30, 165-185.

Kyomo J. (2002) Timing and Synchronization of the Breeding Period in Pilumnus vespertilio (Crustacea: Pilumnidae) in Subtropical Okinawa, Japan. Pacific Science 56, 317-328.

Ladle R.J., Todd P.A. (2006) A developmental model for predicting handedness frequencies in crabs. Acta Oecologica 30, 283-287.

Lane E.W. (1947) Report of the Subcommittee on Sediment Terminology. Transactions, American Geophysical Union 28, 936-938.

Ledesma M.E., O'Connor N.J.( 2001) Habitat and diet of the non-native crab Hemigrapsus sanguineus in Southwestern New England. Northeastern Naturalist $8,63-78$.

Lee S. (1995) Cheliped size and structure: the evolution of a multifunctional decapod organ. Journal of Experimental Marine Biology and Ecology 193, 161-176.

Litulo C., Mahanjane Y., Mantelatto F.L.M. (2005) Population biology and breeding period of the sand-bubbler crab Dotilla fenestrata (Brachyura: Ocypodidae) from Southern Mozambique. Aquatic Ecology 39: 305-313.

Lohrer A.M., Fukui Y., Wada K., Whitlatch R.B. (2000) Structural complexity and vertical zonation of intertidal crabs, with focus on habitat requirements of the 
Spìvak et al. 28

invasive Asian shore crab, Hemigrapsus sanguineus (de Haan). Journal of Experimental Marine Biology and Ecology 244, 203-217.

MacDonald P. D., Pitcher T.J. (1979) Age-groups from size-frequency data: a versatile and efficient method of analyzing distribution mixtures. Journal of the Fisheries Research Board of Canada 36, 987-1001.

McGaw I.J. (2001) Impacts of habitat complexity on physiology: purple shore crabs tolerate osmotic stress for shelter. Estuarine Coastal and Shelf Science 53, 865876.

McGaw I.J. (2003) Behavioral thermoregulation in Hemigrapsus nudus, the amphibious purple shore crab. Biological Bulletin 204, 38-49.

Milke L.M., Kennedy V.S. (2001) Mud crabs (Xanthidae) in Chesapeake Bay: claw characteristics and predation on epifaunal bivalves. Invertebrate Biology 120, 6777.

Morgan S. G. (1996) Influence of tidal variations in reproductive timing. Journal of Experimental Marine Biology and Ecology 206, 237-251.

Nelson K. (1991) Scheduling of reproduction in relation to molting and growth in malacostracan crustaceans. In Wenner A. and Kuris A. (eds). Crustacean Egg Production, Rotterdam: Balkema, pp. 77-113. [Crustacean Issues 7]

Ng P.K.L., Guinot D., Davie P.J.F. (2008) Systema Brachyurorum. Part I. An annoted checklist of extant brachyuran crabs of the world. The Raffles Bulletin of Zoology $17,1-286$.

Ng P.K.L., Tan L.W.H. (1985) "Right handedness" in heterochelous Calappoid and Xanthoid crabs - suggestion for a functional advantage Crustaceana 49, 98-101. 
Spìvak et al. 29

Orensanz J.M., Gallucci V.F. (1988) Comparative study of postlarval life-history schedules in four sympatric species of Cancer (Decapoda: Brachyura: Cancridae). Journal of Crustacean Biology 8, 187-220.

Orensanz J.M., Parma A.M., Armstrong D.A., Armstrong J., Wardrup P. (1995) The breeding ecology of Cancer gracilis (Crustacea: Decapoda: Cancridae) and the mating systems of cancrid crabs. Journal of Zoology 235, 411-437.

Paula J. (1989) Rhythms of larval release of decapod crustaceans in the Mira Estuary, Portugal. Marine Biology 100, 309-312.

Reuschel S., Schubart C.D. (2006) Phylogeny and geographic differentiation of AtlantoMediterranean species of the genus Xantho (Crustacea: Brachyura: Xanthidae) based on genetic and morphometric analyses. Marine Biology 148, 853 - 866.

Reuschel S., Schubart C.D. (2007). Contrasting genetic diversity with phenotypic diversity in coloration and size in Xantho poressa (Brachyura: Xanthidae), with new results on its ecology. Marine Ecology 28, 296-305.

Reyns N.B., Eggleston D.B., Luettich R.A. (2006) Secondary dispersal of early juvenile blue crabs within a wind-driven estuary. Limnology and Oceanography 51, 19821995.

Rodriguez A., Martin J.W. (1997) Larval development of the crab Xantho poressa (Decapoda: Xanthidae) reared in the laboratory. Journal of Crustacean Biology $17,98-110$

Saigusa, M. (1988) Entrainment of tidal and semilunar rhythms by artificial moonlight cycles. Biological Bulletin 174, 126-138.

Shigemiya Y. (2003) Does the handedness of the pebble crab Eriphia smithii influence its attack success on two dextral snail species? Journal of Zoology 260, 259-265. 
Spìvak et al. 30

Simonson J.L. (1985) Reversal of handedness, growth, and claw stridulatory patterns in the stone crab Menippe mercenaria (Say) (Crustacea: Xanthidae). Journal of Crustacean Biology 5, 281-293.

Skov M.W., Hartnoll R.G., Ruwa R.K., Shunula J.P., Vannini M., Cannicci S. (2005) Marching to a different drummer: Crabs synchronize reproduction to a 14-month lunar-tidal cycle. Ecology 86, 1164-1171.

Zariquiey Álvarez R. (1986) Crustáceos Decápodos Ibéricos. Investigaciones Pesqueras $32,1-510$ 
Spìvak et al. 31

\section{FIGURE LEGENDS}

Fig. 1. a) Geographic localization of the study area. b) Cádiz Bay. c) Map of the Corrales de Rota. d) Surface and e) General view of the sampling site.

Fig. 2. Proportion of sediment particles of different sizes and their occupation by Xantho poressa : very coarse gravel $\left(<32 \mathrm{~cm}^{2}\right)$, small cobbles $\left(32-128 \mathrm{~cm}^{2}\right)$, large cobbles $\left(129-512 \mathrm{~cm}^{2}\right)$, small boulders $\left(513-2048 \mathrm{~cm}^{2}\right)$

Fig. 3. Seasonal size frequency distributions of differentiated males and females of Xantho poressa (all samples, see Material \& Methods). Modes fitted by least squares method (see Table 2; procedure described in Bas et al., 2005)

Fig. 4. Sex ratio below cobbles or boulders inhabited by different numbers of crabs; (all samples and density samples, respectively; see Material \& Methods).

Fig. 5. Proportion of ovigerous females of Xantho poressa during the reproductive season, air and water temperature of each sampling date (mean value of the week that includes 3 days before and 3 days after the date).

Fig. 6. a) Mean hepatosomatic (HSI \pm SD) and b) mean gonadosomatic (GSI \pm SD) of Xantho poressa through the sampling period (all samples, see Material \& Methods). c) Mean gonadosomatic index (GSI \pm SD) of ovigerous females with early and late embryos and non ovigerous females during the reproductive season.

Fig. 7. Fecundity, reproductive effort and mean egg weight during most of the reproductive cycle (May-July).

Fig. 8. Summary of rhythmic events during the reproductive season of Xantho poressa. Graph includes daily tidal levels, lunar phases (empty circle $=$ full moon, full circle $=$ new moon $)$, the gonadosomatic index $($ GSI $)$, the proportion of ovigerous 
Spìvak et al. 32

females (POF) and the accumulative number of females releasing larvae in the laboratory (hatching). No hatching data were available in June. GSI, POF and hatching were represented with different scales 
Spìvak et al. 33

Table 1. Two-way ANOVA evaluating differences in Xantho poressa crab density between zones and among seasons

$$
\text { Factor }
$$

Degrees of

MS

F

$\mathrm{p}$

Freedom

\begin{tabular}{ccccc}
\hline zone & 1 & 126.25 & 5.6465 & 0.018864 \\
sampling date & 3 & 51.61 & 2.3083 & 0.079218 \\
zone x sample & 3 & 23.94 & 1.0707 & 0.363738 \\
error & 138 & 22.36 & & \\
\hline
\end{tabular}


Spìvak et al. 34

Table 2. Modes of size frequency distributions of Xantho poressa (Figure 3) fitted by least squares method through the procedure described by Bas et al. (2005) (critical value

$$
\text { of } \chi^{2}=22.36 \text { ) }
$$

males

\begin{tabular}{|c|c|c|c|c|c|c|}
\hline season & \multicolumn{4}{|c|}{$\mathrm{CW} \pm \mathrm{SD}(\mathrm{mm})(\%)$} & $\chi^{2}$ & $\mathrm{p}$ \\
\hline spring & $11 \pm 2.5(15)$ & $18.7 \pm 2(20)$ & $24.2 \pm 2.3(45)$ & $30 \pm 2.3(2)$ & 6.65 & 0.919 \\
\hline summer & $13.2 \pm 3.3(35)$ & $23.1 \pm 2.7(61)$ & $31.1 \pm 1.5(4)$ & & 4.89 & 0.977 \\
\hline fall & $13.7 \pm 1.7(20)$ & $20.4 \pm 2.0$ & $27.5 \pm 3.2(45)$ & & 2.11 & 1 \\
\hline winter & $12.4 \pm 1.6(10)$ & $21.3 \pm 3.8$ & $28.3 \pm 3.4(46)$ & & 3.71 & 0.994 \\
\hline
\end{tabular}

females

\begin{tabular}{cccccc}
\hline season & & \multicolumn{2}{c}{$\mathrm{CW} \pm \mathrm{SD}(\mathrm{mm})(\%)$} & $\chi^{2}$ & $\mathrm{p}$ \\
spring & $10.8 \pm 1.7(4)$ & $17.8 \pm 2.1(81)$ & $22.6 \pm 2.3(15)$ & 7.40 & 0.880 \\
summer & $10.8 \pm 1.7(16)$ & $17.5 \pm 2.2(80)$ & $25.0 \pm 2.3(4)$ & 5.78 & 0.953 \\
fall & $16.3 \pm 2.4(51)$ & $20.4 \pm 1.5(59)$ & 3.27 & 0.997 \\
winter & $15.3 \pm 2.3(33)$ & $20.1 \pm 2.0(67)$ & 4.68 & 0.981 \\
\hline
\end{tabular}


Spìvak et al. 35

Table 3. Two-way ANOVA evaluating differences in female carapace width between reproductive condition of Xantho poressa (ovigerous - non ovigerous) and among sampling dates

Factor

$$
\text { Degrees of }
$$

MS

$\mathrm{F}$

Freedom

\begin{tabular}{ccccc}
\hline sampling dates & 6 & 16.28 & 3.78 & 0.001144 \\
condition & 1 & 0.25 & 0.06 & 0.809082 \\
sample x condition & 6 & 5.53 & 1.28 & 0.263876 \\
$\quad$ error & 393 & 4.31 & & \\
\hline
\end{tabular}


Spìvak et al. 36

Table 4. Comparison of slopes of regression lines between sexes in of Xantho poressa: chelae height - carapace width (cw)

\begin{tabular}{ccccc} 
Factor & Degrees of & MS & F & p \\
& Freedom & & & \\
\hline sex & 1 & 0.017108 & 24.062 & 0.000003 \\
cw & 1 & 1.777748 & 2500.380 & 0.000000 \\
cw x sex & 1 & 0.026611 & 37.428 & 0.000000 \\
error & 129 & 0.000711 & &
\end{tabular}


Spìvak et al. 37
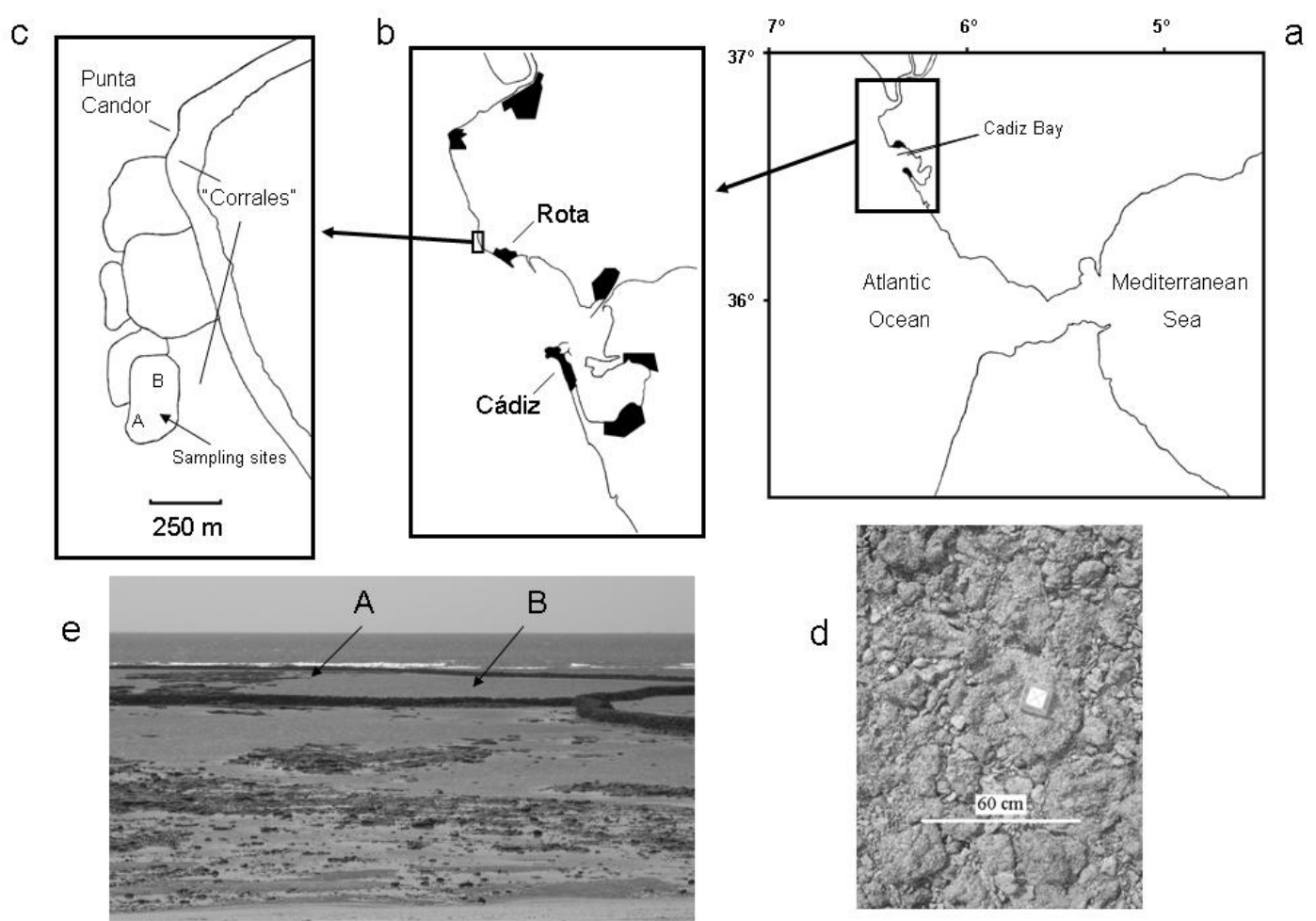

d

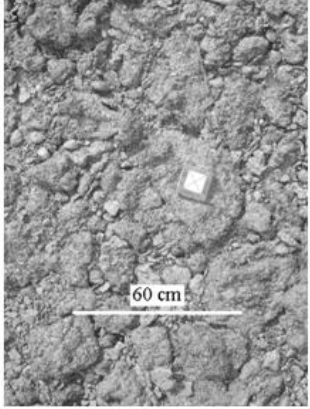

Figure 1 
Spìvak et al. 38

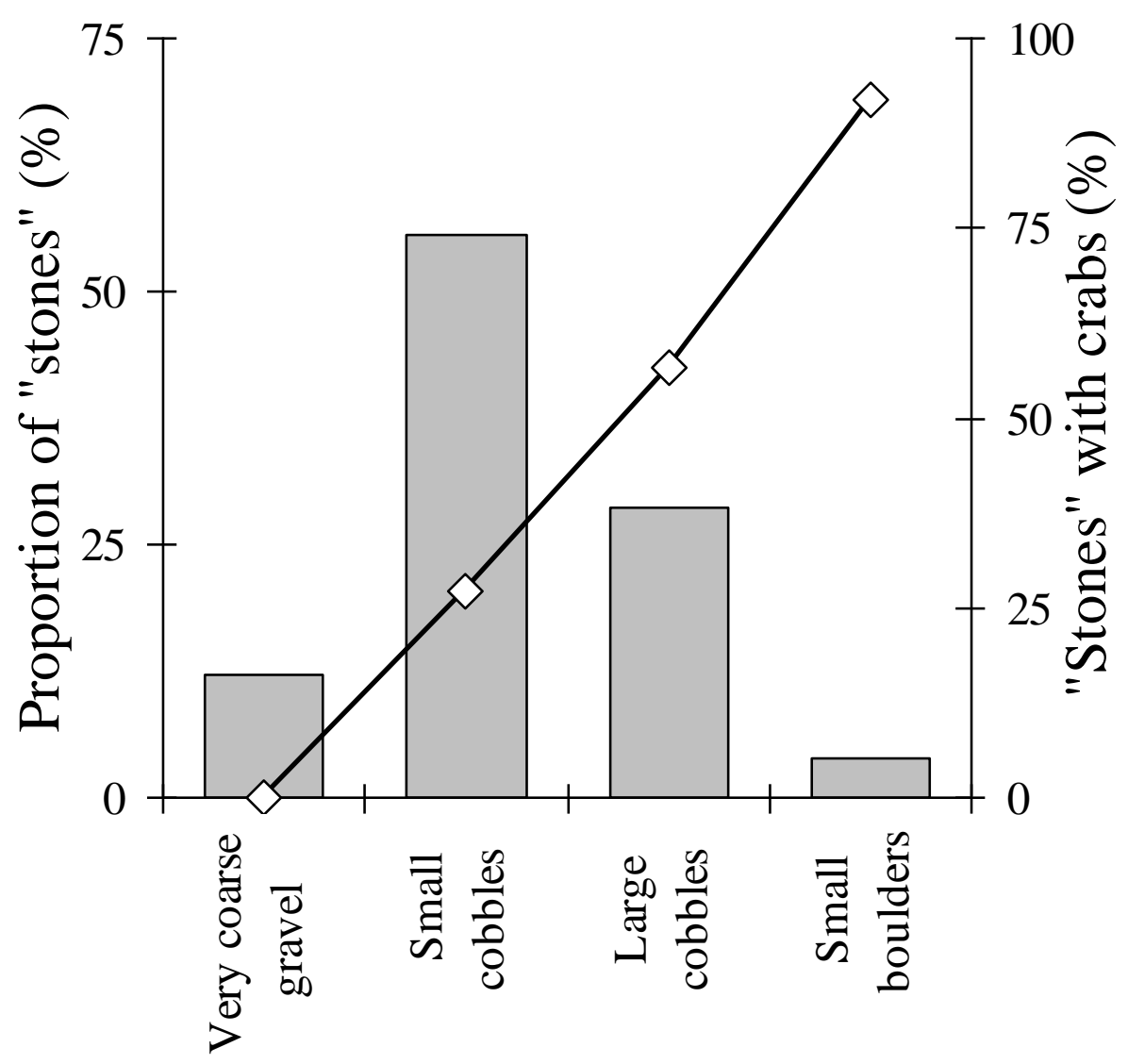

Figure 2 
Spìvak et al. 39

Figure 3

females males
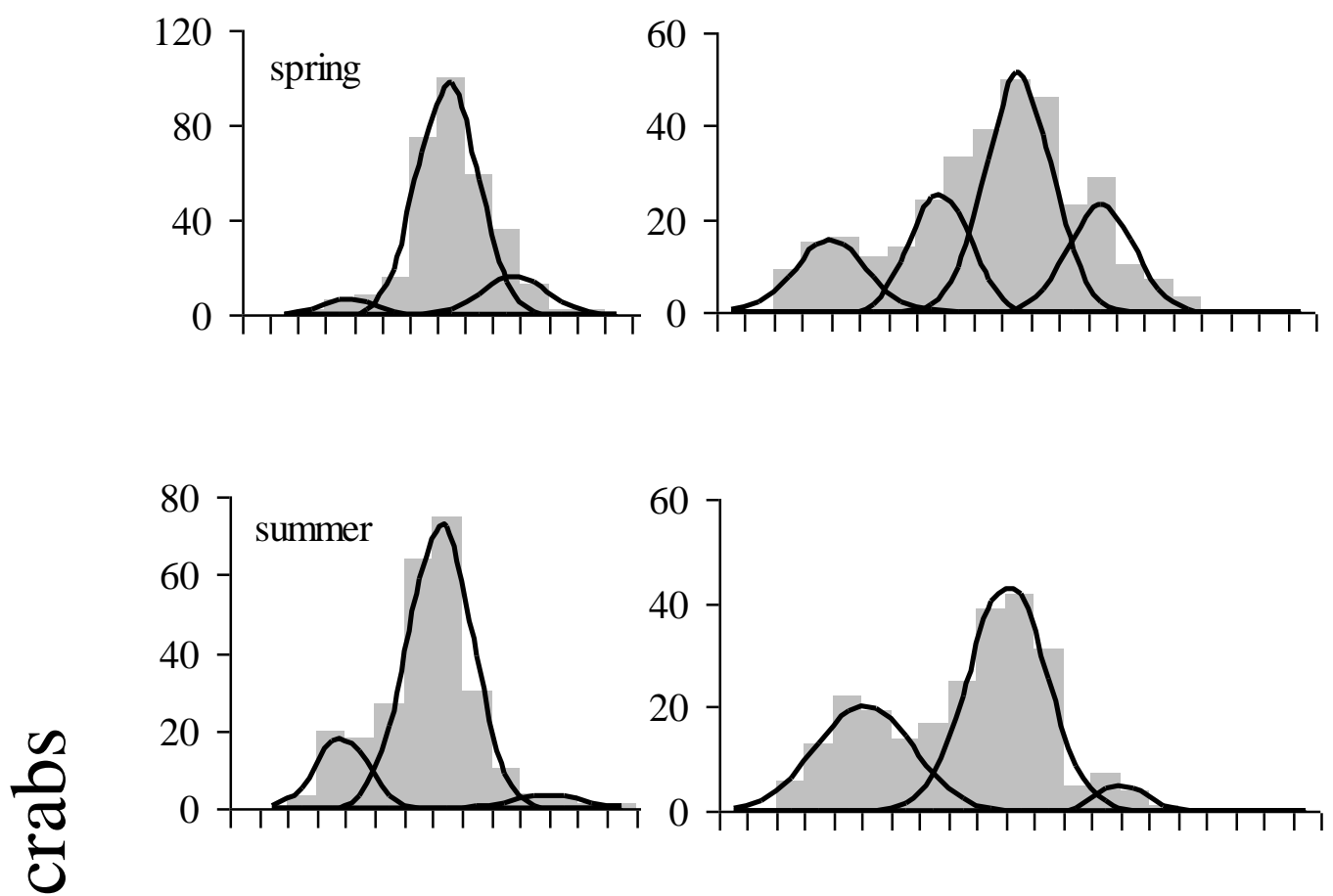

4
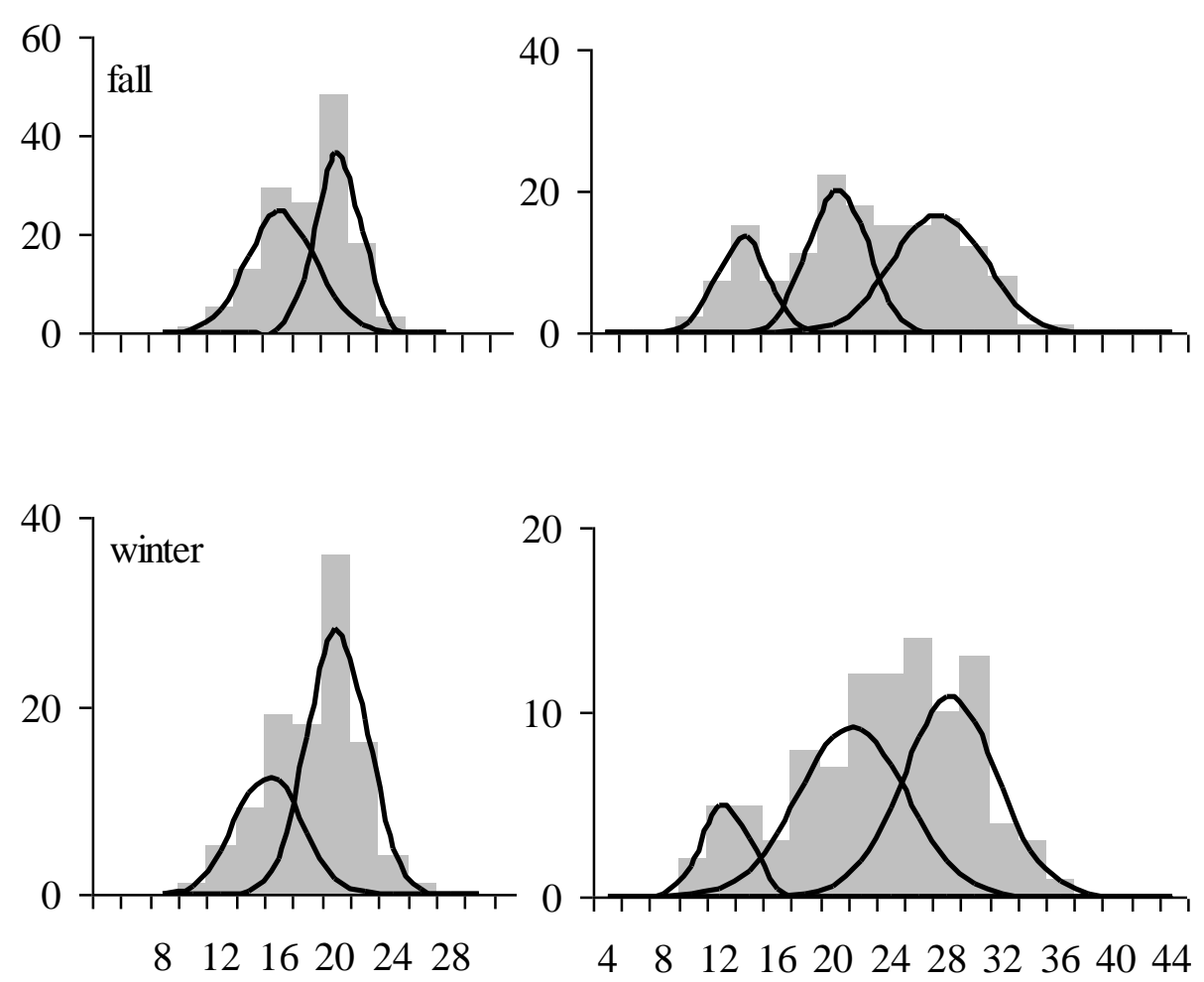

Carapace width (mm) 
Spìvak et al. 40

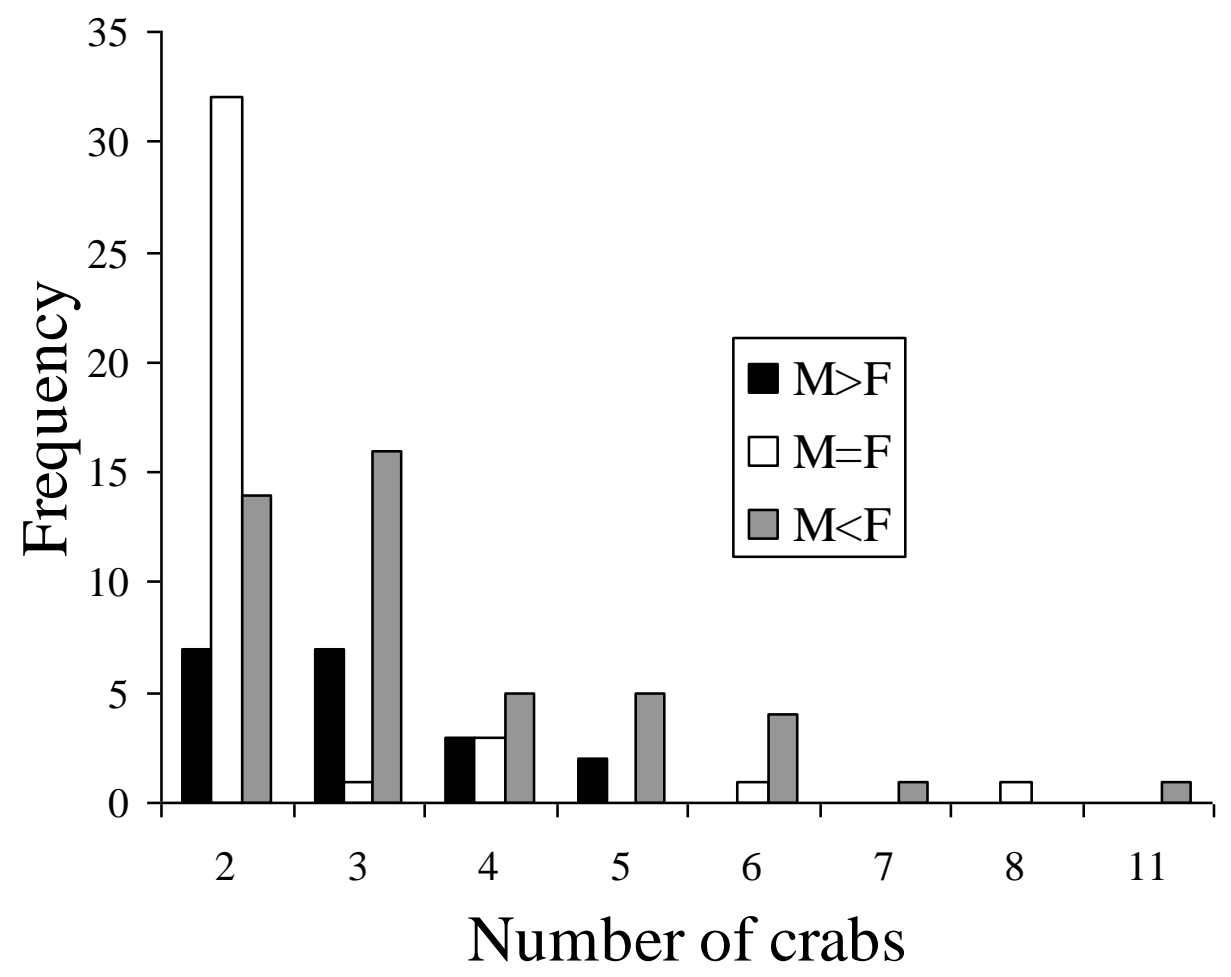

Figure 4 
Spìvak et al. 41

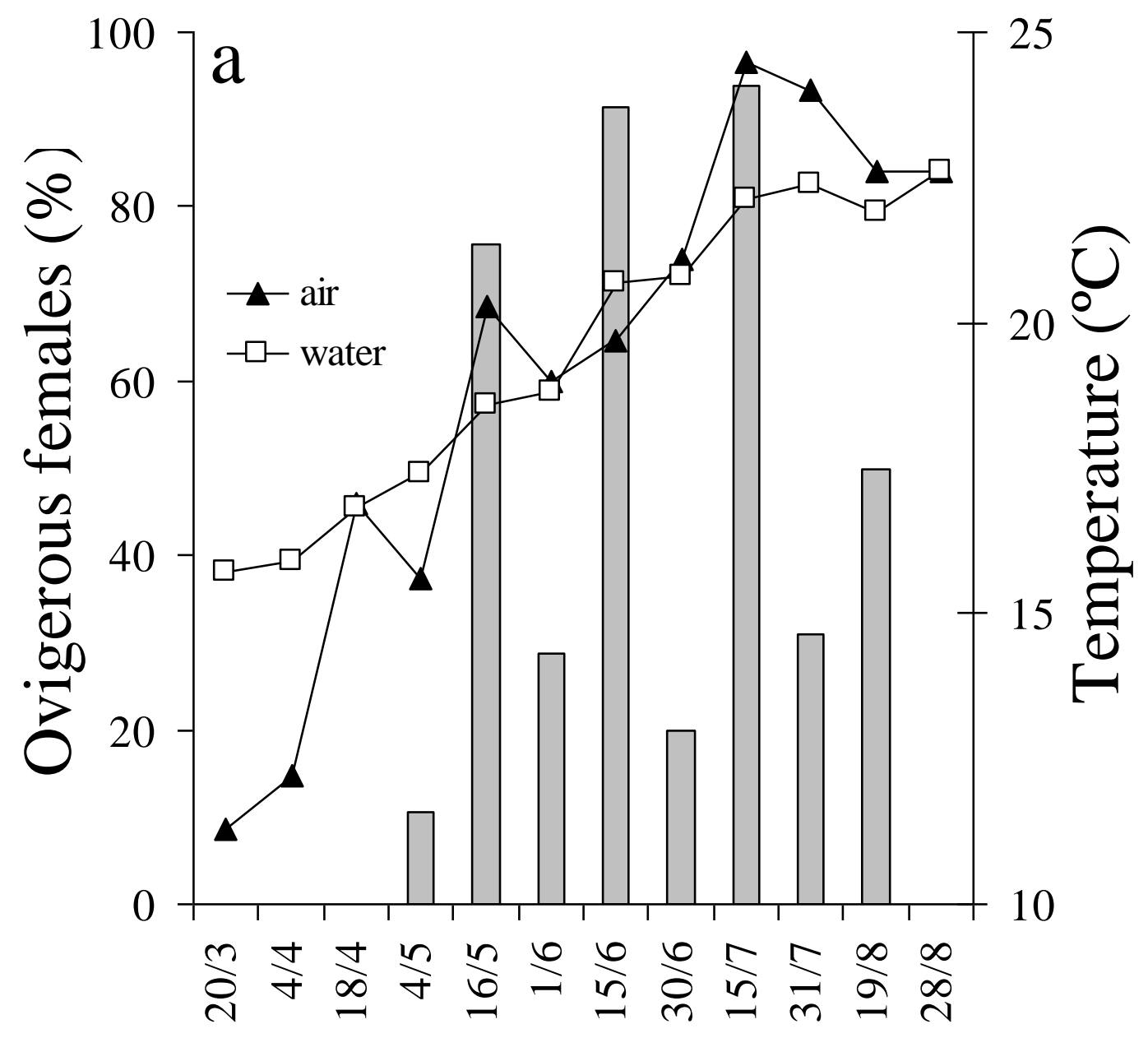

Figure 5 
Spìvak et al. 42

Figure 6

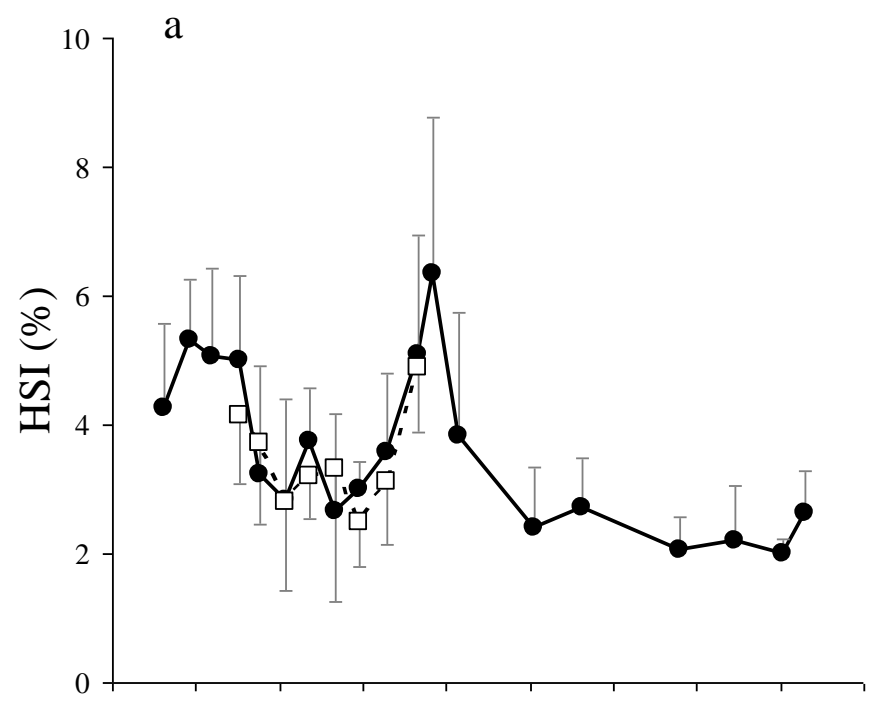

b
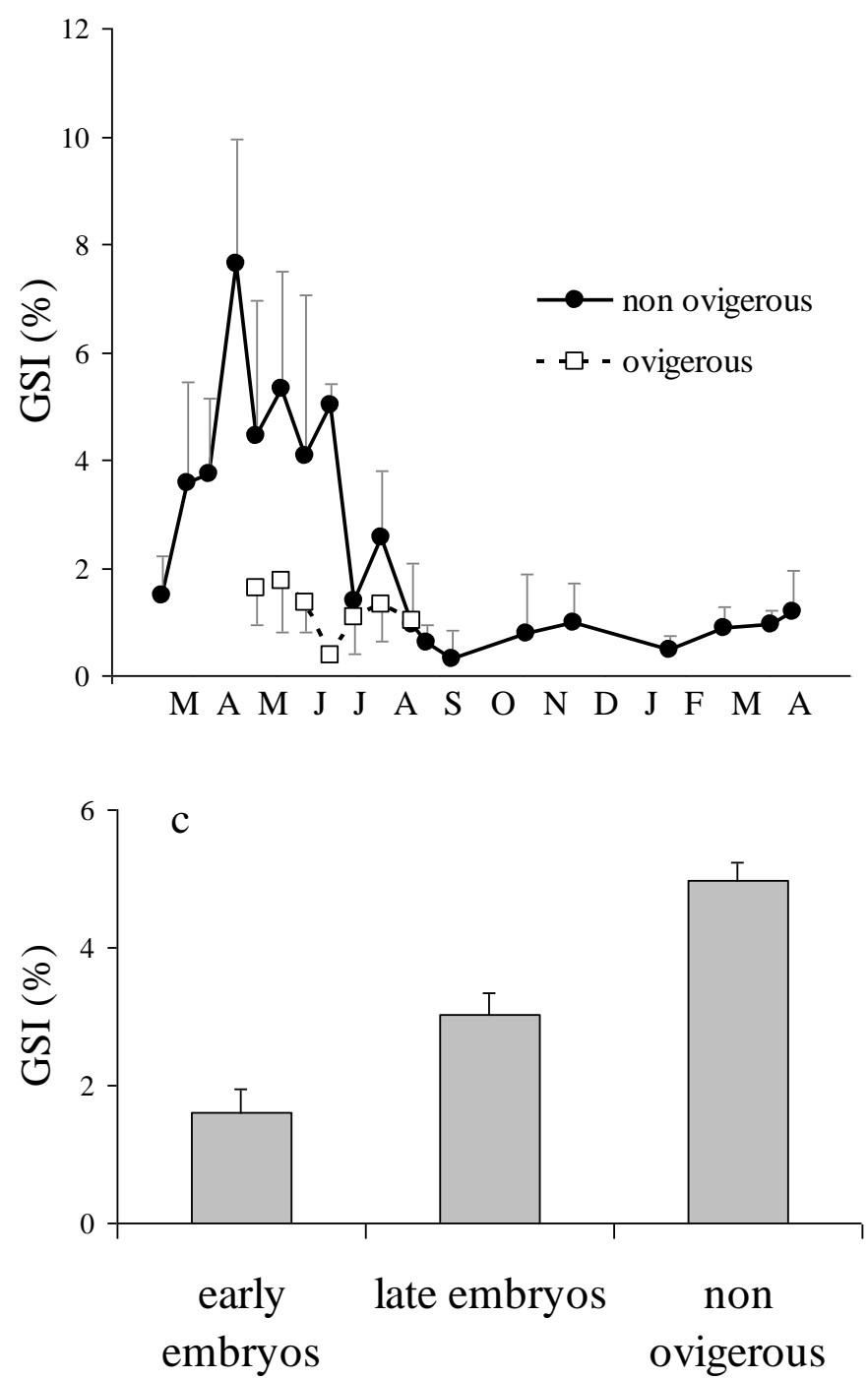
Spìvak et al. 43

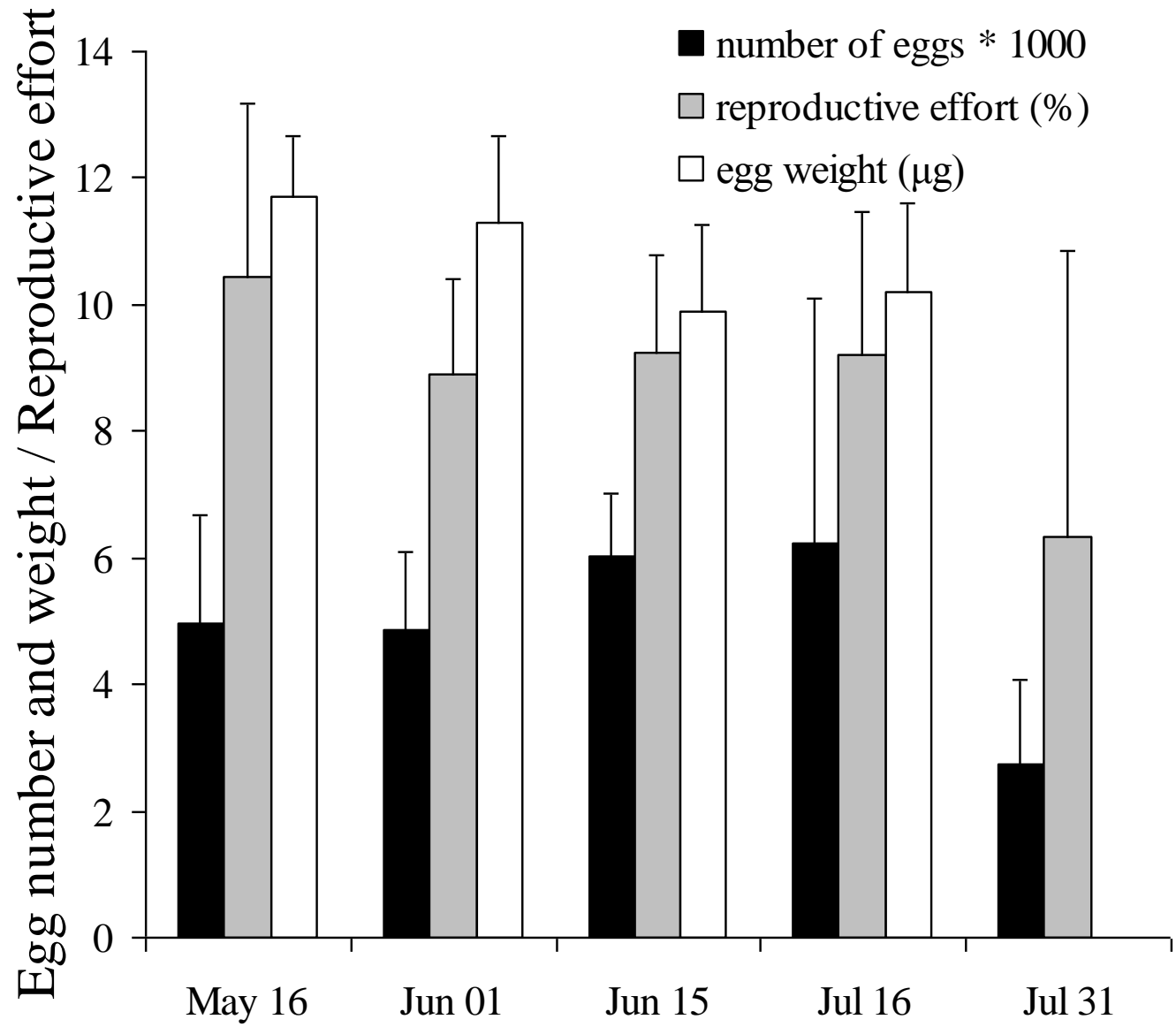

Figure 7 
Spìvak et al. 44

Figure8

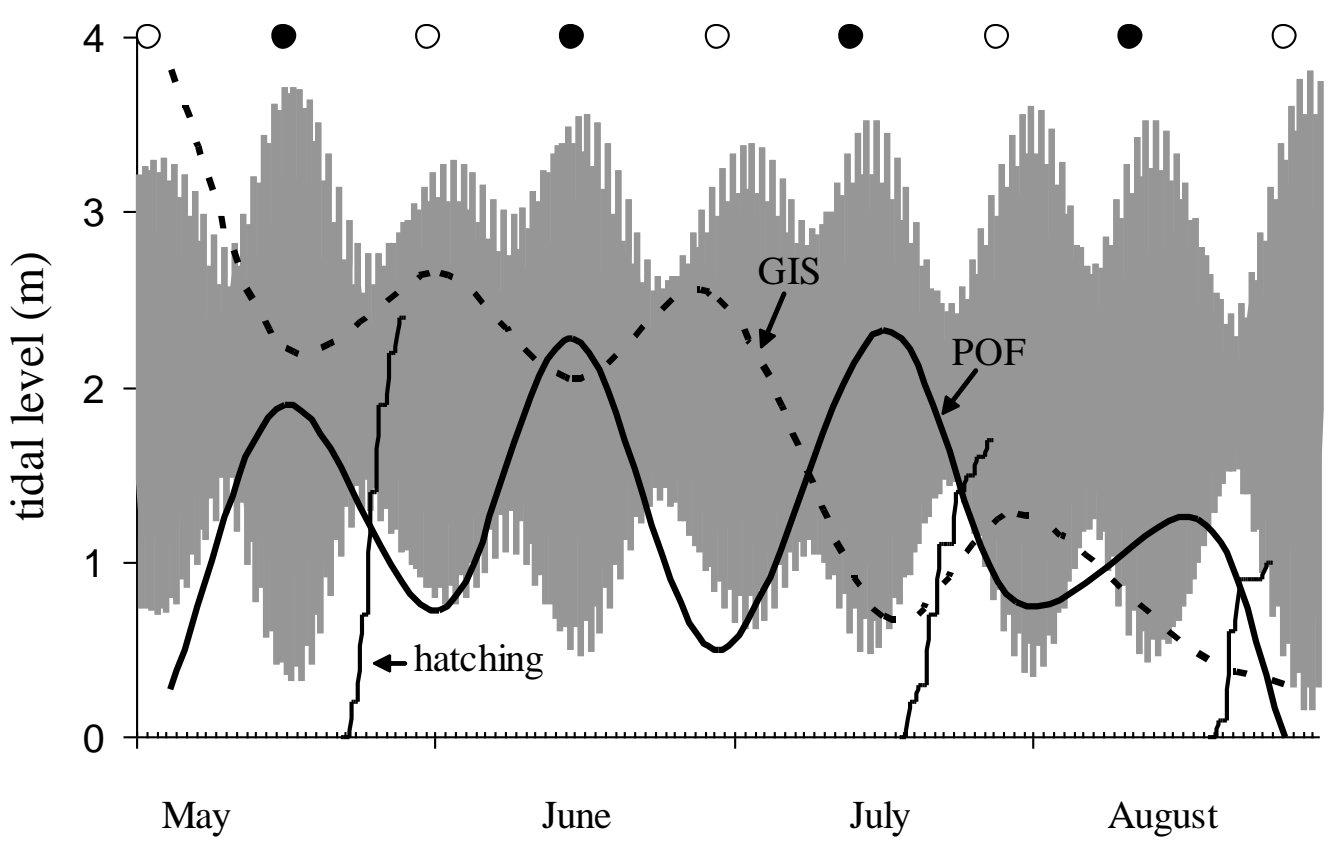

